San Jose State University

SJSU ScholarWorks

Faculty Publications

Health Science and Recreation

$1-1-2010$

\title{
'I Stand Like A Woman': Empowerment and Human Rights in the Context of Community-Based Reintegration of Girl Mothers Formerly Associated With Fighting Forces and Armed Groups
}

\author{
Miranda E. Worthen \\ A Veale \\ University of California - Berkeley \\ S McKay \\ University of California - Berkeley \\ M Wessells \\ University of California - Berkeley
}

San Jose State University, miranda.worthen@sjsu.edu

Follow this and additional works at: https://scholarworks.sjsu.edu/healthsci_rec_pub

Part of the Medicine and Health Sciences Commons

\section{Recommended Citation}

Miranda E. Worthen, A Veale, S McKay, and M Wessells. "'I Stand Like A Woman': Empowerment and Human Rights in the Context of Community-Based Reintegration of Girl Mothers Formerly Associated With Fighting Forces and Armed Groups" Journal of Human Rights Practice (2010): 49-70. https://doi.org/ 10.1093/jhuman/hup028

This Article is brought to you for free and open access by the Health Science and Recreation at SJSU ScholarWorks. It has been accepted for inclusion in Faculty Publications by an authorized administrator of SJSU ScholarWorks. For more information, please contact scholarworks@sjsu.edu. 


\section{'I Stand Like A Woman':}

\section{Empowerment and Human Rights in the Context of Community-Based Reintegration of Girl Mothers Formerly Associated With Fighting Forces and Armed Groups}

This article explores current understandings of empowerment and human rights and the interplay between these two concepts. Drawing on stories that have emerged from a multi-year participatory action research study with young women and girls who were formerly associated with armed groups in Sierra Leone, Liberia, and northern Uganda and had children of their own during the conflict and with young mothers considered by their community to be especially vulnerable, the authors put forward suggestions about how empowerment can happen and the way that the human rights of the most vulnerable in society can be realized.

In the literature on human rights based approaches (RBA) to development, emergency, and transition programs, empowerment is often described as an outcome of using an RBA. Yet through working with extremely vulnerable 'girl mothers', ${ }^{1}$ we have seen that, while human rights based approaches and empowerment are inter-related, their relationship is more complicated than one being a process and the other being an outcome of that process. Indeed, in some instances, it seems as though processes that nurture empowerment are necessary for a human rights based approach to be meaningful and for rights to be realized. In other instances, it appears that for some girl mothers, engaging with one another and with community members as rights holders is part of that very process of empowerment. We argue that neither empowerment nor RBA should be treated solely as processes or outcomes, but rather they should be seen as mutually constitutive, iterative processes towards achieving both empowerment and rights.

\footnotetext{
${ }^{1}$ Throughout this article, we refer to 'girl mothers' and 'young mothers'. We use the term 'girl mother' to refer to individuals who either became pregnant or had a child before the age of 18. At the point of joining the PAR, some of these 'girl mothers' were over the age of 18 , and thus we also refer to 'young mothers', which is a broader term that encompasses individuals between the ages of $15-30$.
} 
This article begins with a literature review of empowerment and human rights theories, and then moves into an illustration of how these concepts have been operationalized in the Participatory Action Research Study with Girl Mothers and their Children in Sierra Leone, Liberia, and northern Uganda (PAR). These examples, while being context-specific, shed light on processes that may happen in other contexts where the target population is an extremely marginalized and vulnerable group. We conclude by suggesting the ways in which these context-specific findings may be more generalizable to other vulnerable populations in countries newly adopting international human rights norms.

\section{Theories of Empowerment and Human Rights}

While the terms 'empowerment' and 'human rights', or 'rights-based approach', are familiar to those working in emergency and transition settings, there is no general consensus about what these terms mean and how they relate to one another. This section reviews the literature on empowerment and human rights and particularly explores the areas in which there appears to be interplay between these ideas.

\section{Empowerment}

Empowerment has taken an increasingly central role in development and humanitarian organizations since the 1980s (Luttrell et al., 2007). Empowerment theory was brought to development practice through the work of Freire and through the feminist critique of Women in Development. The 1995 Beijing Platform for Action further encouraged the focus on empowerment, and specifically included the perspectives of youth and girls, identifying that they often experienced even lower status than women or boys (Worthen, 1994). Within the development context, empowerment has been conceptualized as a process, an outcome, or some combination of the two. Although there remains little consensus about what empowerment means, development agencies, governments, inter-governmental organizations like the World Bank, and others now agree that empowerment is good. Empowerment, as Parpart, Rai and Staudt (2002: 3) have argued, has 'become a 'motherhood' term, comfortable and unquestionable, something very different institutions and practices seem to be able to agree on'. 
Many definitions of empowerment focus on participation in decision-making. For example, Bystydzienski (1992) describes empowerment as a process through which a person who is oppressed gains control over her life. The World Bank defines empowerment as ‘increasing the capacity of individuals and groups to make choices and to transform these choices into desired actions and outcomes' (Alsop and Norton, 2005: 4). The UK Department for International Development defines empowerment as “'individual’s acquiring the power to think and act freely, exercise choice, and to fulfill their potential as full and equal members of society’” (Smyth, 2007: 584).

Rowlands argues that empowerment goes beyond this, writing that empowerment 'must also include processes that lead people to perceive themselves as able and entitled to make decisions...' including, 'undoing negative social constructions, so that people come to see themselves as having the capacity and the right to act and influence decisions’ (1997: 14, italics in original). Rowlands agrees with Kabeer who said that 'such power cannot be given; it has to be self-generated’ (Kabeer, 1994: 229). For Rowlands, at the core of the process of empowerment is a psychological process of change, including the 'development of self-confidence and self-esteem, and a sense of agency, of being an individual who can interact with her surroundings and cause things to happen' (1997: 111, 113). 'Dignity’, meaning 'selfrespect, self-esteem, and a sense of being not only worthy of respect from others, but of having a right to that respect’, is also essential to Rowlands' notion of empowerment (1997: 113, 129 - 130).

While some people view empowerment as an aim in and of itself, others view empowerment as of instrumental value for increasing the effectiveness of development aid, improving governance, and contributing towards economic growth (Alsop, 2005: vii). Those who write about the instrumental use of empowerment recognize its 'intrinsic' value. While acknowledging the importance of empowerment for individuals, Yuval-Davis also argues that 'empowerment of the oppressed, whether one fights it for one’s own - individual or group - sake, or that of others, cannot by itself be the goal for feminist and other antioppression politics’ (Yuval-Davis, 1994: 193). For Yuval-Davis, social change that is the product of empowerment is essential. 
Many who write about empowerment write of the kind of power that is enacted in empowerment as ‘power within'. While we agree with Kabeer that empowerment cannot be 'given' by one party to another, we disagree that empowerment is strictly 'self-generated'. Instead, we believe that empowerment, like power, is interpersonal and inter-relational. If, as Foucault (1980) argues, power is expressed in interactions, empowerment, as well, happens in interactions. It does not emerge from within a person without context. Empowerment can emerge as a property of a conversation or an interaction. Thus while empowerment shapes an experience from ‘within', it is still deeply relational.

Weingarten and Cobb (1995) propose that ‘discursive practices’ can be empowering. Their notion of empowerment hinges on recognition: a sense of empowerment can be generated through 'one person experiencing another person as accepting and elaborating what she has to say' (1995: 259). The act of accepting and amplifying another person's meaning can occur through conversation, or, as will be described later in the case of the PAR, through collective actions, such as putting on a drama.

The achievement of this initial psychosocial state where a person sees herself as worthy of dignity and respect cannot be considered in isolation from the experience of being part of a collective. Rowlands identifies this aspect of empowerment as 'collective empowerment', which she asserts is intertwined with personal empowerment in a circular manner: 'participation in the group may feed the process of personal empowerment, and vice versa' (1997: 115). The examples given later in this article illustrate the importance of this sense of oneself within a community allowing participants to, as Rowlands writes, ‘achieve a more extensive impact than each could have had alone’ (1997:15).

Thus, we propose that empowerment is an iterative, relational process through which a person gains self-respect and grows to see herself as worthy of dignity and respect by others. A person increases her sense of agency - meaning she becomes aware of herself as one who is able and entitled to make decisions, increases her capacity to make those decisions, and gains an ability to influence the circumstances of her life. The change that happens during this process is not just intrapersonal, but social, producing a shift in power relations within a family, community, or other group. This process does not always happen steadily; rather a person may experience great improvements along with setbacks. 


\section{Human Rights Based Approaches}

Although different authors define rights based approaches (RBAs) differently, there are key similarities. The United Nations High Commission on Human Rights describes RBA as 'a conceptual framework for the process of human development that is normatively based on international human rights standards and operationally directed to promoting and protecting human rights' (Office of the United Nations High Commissioner for Human Rights, 2006: 15). Former Commissioner for Human Rights, Mary Robinson expands, “'the principles in question are: participation, empowerment, accountability, non-discrimination, and express linkages to international human rights norms and standards'” (2005: 38). Hutchings writes that RBAs 'start from the position that individuals possess inalienable human rights.... They recognize people as rights-holders...' (2005: 1).

Rights based approaches can be used at the micro-level, where they shape organizational practices in emergency, transition or development settings, and they can also be adopted at the macrolevel, where they seek to alter institutions to better respect, protect, and promote the rights of citizens. Although this article will chiefly focus on RBAs at the micro-level as agencies and practitioners in development, emergency, and transition settings operationalize them, a brief detour to frame the macro will be useful.

Robinson contextualizes the direct link between rights and empowerment that is implied at the macro-level: 'The recognition of a 'right' to health or education, arising out of treaties and other international commitments, implies corresponding legal obligations of national governments as well as of the international community. As a consequence of that recognition, those who are poor and marginalized are empowered, and their participation rendered effective' (2005: 39). Uvin makes the connection this way: 'the rubber of an RBA starts hitting the development asphalt when it leads to a more macroinstitutional approach to development work, seeking to empower people through legal and policy reforms that establish key conditions for the enjoyment of their rights' (2004: 130 - 131). Thus, at the macrolevel, institutional changes are thought to produce empowerment in individuals by creating the legal 
structure for them to claim their rights. At this macro level, RBAs have been critiqued because of their failure to address pre-existing power relations, especially those between international actors, including different states (c.f. Uvin, 2002; Nyamu-Musembi and Cornwall, 2004). Similarly, while nations may pass laws that conform to international human rights treaties quickly, implementation of these standards remains far more challenging. While we believe that institutional reforms that expand a nation's ability and responsibility to respect, protect, and promote the rights of its population are imperative, we do not believe that reforms at this level alone lead to empowerment.

Various humanitarian and development actors have adopted RBAs at the micro-level. At this level, RBAs aim to promote 'higher levels of citizens' empowerment, ownership, and free, meaningful, and active participation' (Robinson, 2005: 38). RBAs may be adopted not just as an approach to programming, but also as a 'lens' through which all the work of the organization is envisioned (CARE International, 2005: 1). CARE describes the workings of an RBA at the micro-level: an RBA 'deliberately and explicitly focuses on people achieving the minimum conditions for living with dignity (i.e. achieving their human rights). It does so by exposing the roots of vulnerability and marginalization and expanding the range of responses. It empowers people to claim and exercise their rights and fulfill their responsibilities' (CARE International, 2005: 1). Thus, we can see that the discourses of human rights and empowerment are overlapping and related with CARE even equating dignity with achieving human rights.

As can be seen from the quotations above, the relationship between empowerment and a rights based approach is conceptualized at both the macro- and the micro-levels. At each of these levels, empowerment can be viewed as an outcome of using an RBA and as a part of the process through which rights are achieved. At the macro-level, institutional change that better protects rights is seen as empowering, and an empowered citizenry is better able to press for that institutional change. At the micro-level, it is seen as empowering to know ones rights and have them fulfilled, and having that knowledge empowers individuals to claim their rights. In this manner, rights and empowerment are seen as intertwined. 
Examples from the PAR study allow for an exploration of how empowerment and human rights based approaches relate and co-evolve when working with girls and young women considered the 'most vulnerable' in their communities (Robinson and McKay, 2005). In the next two sections, we give the background of the PAR study and provide examples of how the relationship between empowerment and human rights has evolved in the PAR.

\section{The PAR Study}

Background: The Situation of Girl Mothers Formerly Associated with Armed Groups

Young women and girls have been recruited into armed groups in conflicts throughout the world and have played roles ranging from fighters to porters and from cooks to captive wives (McKay and Mazurana, 2004). Many girls and young women become pregnant and have children during the conflict as a result of rape or in the context of partnerships formed with 'bush husbands' (McKay and Mazurana, 2004; Coulter, 2006). At the end of the conflict, instead of going through formal processes of disarmament, demobilization, and reintegration (DDR), girls and young women with children often return to their communities or settle in new communities on their own or with a peer group (McKay et al., 2006).

DDR efforts have been adult driven and out of touch with young people's perspectives, goals, and capacities. This is even more markedly so in the case of girl mothers. Formal DDR processes are designed to remove weapons from circulation, ensure force restructuring and create a durable end to hostilities, but girls and young women often do not carry arms and, despite playing a role in the conflict, are not perceived as threatening to peace or stability. Formal DDR processes have discriminated against girls and women and have taken into account neither the gendered nature of recruited children's war experience or the unique, gendered situation of young women and mothers after exiting the armed forces or groups (McKay et al., 2004). 'Armed, adult male fighters', Mazurana et al. (2002:116) write, 'are the near exclusive priority for most disarmament, demobilization, and reintegration (DDR) programs, significantly marginalizing all children, but girls in particular'. 
Evidence from several conflicts suggests that stigma against girls and women is so great that many who are eligible to go through DDR, still choose not to go through formal or even informal (e.g. NGO arranged) reintegration programs, hoping to avoid further marginalization. Yet, young women and girls who return from armed groups with children face stigmatization and marginalization from communities, whether they go through reintegration programs or return independently (Burman and McKay, 2007). Young mothers are often viewed by the community as having violated community norms by having children outside the recognized societal marriage norms (McKay et al., 2004; McKay et al., 2006). They are frequently labeled as sexually promiscuous and can be regarded as 'spiritually polluted' (Denov, 2007; Green and Wessells, 1997; Wessells, 2006). In addition, these young mothers have often developed attitudes or habits during their time in the armed groups that are considered culturally inappropriate, for example getting into fights or cursing.

Community members themselves are also recovering from the devastating effects of war, and individuals find it challenging to imagine how they can help young mothers recover, preferring to render the young mothers and their children invisible so they can focus on rebuilding their own lives. One community leader in Freetown, Sierra Leone, for example, told us: 'It is not that the parents were wicked, but they do not have enough to feed themselves much less a girl when they don't even know who impregnated her. To feed someone when they don’t know who impregnated her is very hard'. In other communities, the fear of 'spiritual pollution' from girl mothers and their children also contributed to their isolation by community members (Betancourt et al., 2008).

\section{The Participatory Action Research Study with Girl Mothers and their Children}

The PAR study was initiated in October 2006 in response to a growing awareness that the needs of girls and young women who had children while associated with armed groups were not being met through traditional DDR programs (Robinson and McKay, 2005; McKay and Mazurana, 2004). The study seeks to learn what successful reintegration means to young mothers and what can be done to support them in 
achieving reintegration, as they understand it. While a full description of the PAR is beyond the scope of this article, some background to the project will be helpful.

The study is jointly coordinated by the authors and operates through a partnership with ten child protection agencies (NGOs) working in Liberia, Sierra Leone, and Uganda. Three country-based African academics also work with the study. Each partner agency operates in two locations, forming groups of approximately thirty girls and young women who had children while they were associated with armed groups and including a smaller number of girl mothers who were not associated but were considered by the community to be especially vulnerable. ${ }^{2}$ Communities themselves defined vulnerability and often chose to recruit girl mothers into the PAR who were particularly young, orphaned, disabled, or victims of sexual violence. In all, over 650 girls and young women and over 1200 of their children have been a part of the study in twenty communities in the three countries. Just over $70 \%$ of the young mothers are formerly associated with armed groups. The average age of participants upon enrollment across the three countries was 20, with Ugandan participants being on average two years younger and Sierra Leonean participants being on average two years older.

As may be inferred from its title, the methodology and philosophy of the PAR is participatory action research. Participatory action research has been defined as 'an approach to research that aims at promoting change; that occurs through a cyclic process of planning, data collection, and analysis; and in which members of the group being studied participate as partners in all phases of the research, including design, data collection, analysis, and dissemination' (Brown et al., 2008). In the context of this study, the girls were located at the center, with important decisions being made by them while the agencies and organizers provided support, resources, and monitoring.

PAR emerged from Paulo Freire’s Pedagogy of the Oppressed (1968) and has been adapted to the field of development, most richly by Robert Chambers (Freire, 1970; Chambers, 1994). PAR privileges 'local knowledge' and situates the participant as the expert with respect to his or her own situation. Other

\footnotetext{
${ }^{2}$ The decision was made to not exclusively recruit formerly associated girl mothers because of concerns that focusing on this population could further stigmatize them (Robinson and McKay, 2005).
} 
core principles of PAR are respect for the local community and inclusivity. PAR is not a singular methodology, but rather a set of principles with a basket of techniques and approaches that can be adapted to particular contexts.

The structure of this PAR is different in each field site and in each country because of distinct approaches to organizing. In Sierra Leone and Liberia, organizations collaborate but do not attempt to create a universal approach. In Uganda, the four agencies created an integrated budget and hired a research coordinator to facilitate the study in the field sites. Therefore, there is no unified history that perfectly captures the nuances of how the study developed in each site. However, a general framework for how the study unfolded in each field site can be outlined.

Each country team of child protection agencies began by identifying communities where there were likely to be a large number of formerly associated girl mothers. Once these potential field sites were identified, agency personnel began outreach to local leaders and stakeholders, specifically reaching out to elder women and midwives. The study was explained to these local community members and there were a series of engagements to assess whether collaboration between the community and the PAR would be possible. If community members were supportive of the PAR, then they helped to identify a small number of girl mothers who were formerly associated or identified as particularly vulnerable. Agency staff members then contacted these girls and young women and, over a period of days or weeks, explained the PAR. In some sites, elders recruited the full cohort of thirty girl mothers, while in other sites the initial group of girl mothers recruited other girl mothers that they knew to join the project. All participants who agreed to join the PAR went through an informed consent process according to a protocol accepted by the University of Wyoming Institutional Review Board.

After recruitment, participants were provided training on how to do research and supported in conducting research using a wide array of modalities to learn from each other, their children, other girl mothers, and community members about the problems girl mothers face in their community. Research frequently took the form of focus group discussions led by participants, interviews, and improvised dramas and songs. The young mothers then shared what they had learned and decided upon social actions 
to address some of the problems they identified. While at this point all sites diverged, there was a remarkable similarity to the obstacles identified in each community, which were in the critical areas of livelihood, health, and education. In addition, the participants all identified stigma and lack of social support from family and community as further barriers to their successful reintegration. The structure of the PAR was such that every group of girl mothers was entitled to a small amount of social action support funds to help them carry out their plans.

Groups did not just choose a singular social action, but frequently began several at one time. For example, one group hired a local teacher to give them evening literacy classes, began individual petty trading businesses funded by micro-credit, and launched a group-run cassava farm. Later, they used the profit from their cassava harvest to pay for a nurse to educate them on how to better care for their children. Throughout this time, the group met regularly, sharing their experiences and getting social support from one another. When any member of the group was ill, a delegation would visit her at her home and offer support, sometimes loaning her money to get medical care. In another community, some members of the group decided to engage in formal schooling while others pursued vocational training. The group used a portion of the social action funds to pay for tuition.

Unlike in most child protection programs, agency field staff often found that their role in the PAR was to respond to requests by girl mothers for specific kinds of training or assistance or to help the girl mothers think through decisions like which livelihood project to embark upon by asking questions of the girls, but leaving them to make the final decision. This flexibility meant that groups were not constrained in their choices and that if one project did not meet with success, they had a chance to try something new. In the course of the three years, groups experimented with several different income generating activities. Often the groups began by using micro-credit to fund individual petty trading. Group members would purchase goods like kerosene or flour in bulk and sell the products in their community. Others started hair-braiding salons, sometimes working with other young mothers in the project. These small individual businesses were often followed by a larger group project. In rural communities, participants requested access to land from community members and were often granted farming rights. Some groups hired local 
boys to clear the land for them and then farmed cassava or groundnuts. Several groups collectively raised goats or pigs. Groups in towns began restaurants, soap making businesses, and cloth weaving collectives. One group raised money by putting on parties for the entire community, charging entry fees and hiring popular musicians as entertainment.

Beyond the immediate economic benefit each of these activities generated, the participants had to renegotiate relationships with their community as a result of the various activities they sought to undertake. For example, in several communities where the girls began petty trading, community leaders made announcements in the market that the young mothers' markets were to be respected and that anyone who purchased items on credit had to pay them back. These explicit statements of support were very meaningful for the participants. In some cases, the girls' selected activity created challenges in the community. In one community, for example, several leaders refused to permit the young mothers to graze their goats in the village, even though other community members grazed their goats openly. Several meetings were held to negotiate where the goats could be kept and who would benefit when the goats had kids.

In addition to these income generating activities, a variety of social support initiatives emerged within the groups. When a participant was ill or bereaved, others in the group would visit her. In many communities, girl mothers would cook or do their washing together. If several participants were in school together, they might share an essential book instead of each having to purchase it separately. While these activities were uncoordinated and ad hoc, participants identified them as critical to their experience of the PAR.

The PAR methodology is highly untraditional, even for those agencies already using human rights based approaches, and committed to child participation and empowerment. Indeed, all those engaged in the PAR, from the organizers, to the agency staff, to the academic partners, had to learn to let go of power and authority and truly let the participants decide the course of the project. We had two mottos to help us remember the key tenets of the study: 'If it is not done by the girls, it is not PAR' and 'No research without action'. These two mottos helped us remember to give the participants the space and 
the time that they needed to learn about their situations, decide about the problems needing attention, and creatively address those problems. Our role as organizers and agencies was to facilitate their process, not to let our own agendas dominate.

\section{Empowerment and Human Rights in the Context of the PAR}

Although empowerment was not the explicit aim of the PAR, the PAR began with the premise that the girls were the experts on their own situations. The process that the participants went through in order to learn about each other, identify their common problems, and take action to solve those problems seems to have enabled empowerment. And while similarly human rights achievement was not the explicit aim of the PAR, many of the barriers that they identified also fit within a human rights framework. While the participants themselves did not often identify their claims as human rights claims, as the programs continued and the girl mothers became more fully part of their communities, they were able to draw on several different mechanisms to promote their rights, be protected from violations, and enforce accountability for violations of their rights. While in many instances, the girls did not avail themselves of legal protection, they did locate local structures of authority that they trusted and decided could best help resolve a situation to their benefit.

We present the qualitative evidence to support this description largely through the voices of the young mothers in the PAR themselves. These quotes are taken from semi-structured focus group discussions, case studies provided by the girl mother participants in the form of monthly reports, and discussions with agency staff working on the PAR. Unless otherwise stated, we have selected quotes that we believe are representative of the experience of many participants in the PAR. In this section, the following issues will be addressed in turn: the process of building empowerment through relationships with outsiders associated with the PAR, other participants, community members, and family members; how rights claims have been made by the participants; and the kinds of resistance that empowerment and rights claims have met with. 
The relational process of empowerment

When the PAR began, many young mothers were surprised that anyone would care about them enough to launch a program that focused on their needs. Agency staff and the organizers often had to meet with communities and participants several times to gain their trust that the PAR was real. One Ugandan participant put it this way: 'we have never seen a project which cares for girl mothers'. During her first meeting, she said, 'I had no idea that you cared about me... why do you care about me'? She was used to community members calling her 'expired'. Other young mothers talked of community members calling them names like 'rebel wife' or 'kolonko' (prostitute) and calling their children 'rebel baby' or 'Kony's baby'. Several months into the PAR, the Ugandan participant told how she and the other young mothers in her site 'were very much encouraged, now that we know that people are caring for us'.

The support and caring from outsiders is complementary to the support that the young mothers began to feel from one another. The following two quotes highlight the transformative impact of mutual sharing between girl mothers at the beginning of the PAR. The first refers to a drama that the young mothers improvised together about what it was like for them when they returned to their community after the war.

I thought that I was the only one that was hated. When I saw in the drama that others were also treated like that I no longer felt alone.

Our meetings have created a sense of one-ness among each other and now we share our burdens. We are each other's sisters.

Both these young mothers experienced a transformation through sharing their stories with others who had similar experiences of stigmatization and marginalization. Through working together on a drama, the first young woman had the experience of seeing her own story reflected back to her. The second young woman experienced this same 'amplification' and 'elaboration' of her story through sharing that emerged in the meetings that the young mothers held with each other. Both young mothers no longer felt isolated or alone, but understood their own experiences within the context of a broader social group. 
Several participants expressed how confidence placed in them by the organizers, the agencies, and the other girl mothers involved in the PAR altered their sense of self and gave them an incentive to try to lead better lifestyles. In one community where the young mothers had decided to start a microcredit project to support their livelihood development, one young mother put it this way:

So little ended up helping so much. The little you gave me made me want to take better care of myself. I now try to get good clothes and wash my skin and brush my hair and eat good food. The little bit you gave me made me try harder.

Another woman reported that she no longer spent her money on 'drinking and smoking' because 'from within I feel a change'. Prior to the PAR, these two young women had internalized the disrespect they felt from others in their community. Through the PAR, they experienced what it was like to be cared for, treated with dignity, and to be relied upon, which motivated this change from within. These young women were now beginning to think of themselves as worthy of respect, dignity, and the trust placed in them.

As Rowlands describes, this emergent sense of personal empowerment and sense of connection with others in similar circumstances helps facilitate expressions of collective empowerment. This is well illustrated by another young mother who told us about a drama that her group had performed publicly for the community:

We did a drama about what it was like when we came back from the bush and people shied away from us. The drama also reflected the alienation that we felt when we came back.... We did our play to the community and they said that they wanted to join us and join in our activities. Before, others were shy of us, and now, they talk upright to us. We used the drama to bring those who were shy of us closer again.

This young woman told her story using only 'we' statements. She understood that she was not alone others, too, had been stigmatized. Because those in her group had shared their stories and gained a sense of validation from learning that their stories were similar, the group was able to seek collective recognition for their experience from their community. The group of girl mothers as a collective enacted 
the story of what it had felt like to come back to the community and be isolated before the very people who had made them feel alienated. In this instance, the community did recognize them: community members altered their treatment of the girl mothers and now talk 'upright' to them. Ending this isolation and alienation by community members was the first step towards the young mothers gaining a full position in their community. One young woman described her new sense of acceptance by the community this way:

I am now respected in my community. I dress fine. When there is [a] meeting, I attend and I am not afraid to make any contribution. When I go to the market to do business... people admire me, especially when I tell them that this is my business.

Many of the PAR participants cite dressing better and taking care of their appearance as a reflection of new self-confidence as well as reinforcing a positive sense of self. This young woman found that knowing she was respected made her feel free to contribute in meetings and at the market, which also reinforced her sense of pride and belonging.

Many young women experienced increased support from their families soon after the PAR began. Several participants speak about how their parents would let them use the family bicycle to get to meetings or how they would set aside a bowl of rice for them if they missed a meal. For others, respect from their community seems to have grown before they experienced a shift in their family relationships. In either direction, however, feeling empowered and respected with regards to one group facilitates empowerment in other domains, as can be seen in the following quote:

My mother used to abuse me and blame me for my children, but now I make soap that the community buys, my mother sees me better.

In this instance, the young woman had experienced a shift in her relationship to her community and attributed to that shift a transformation in her relationship with her mother. Where she had once been viewed as worthless in the community, now the community recognized her soap-making skill and people engaged with her as a saleswoman, purchasing her products. Her mother, who had previously abused and blamed her, shifted her perception after observing how community members saw her daughter and, 
presumably, noting that her daughter was engaged productively in supporting herself and her children. The young woman does not speak about her own sense of self worth changing. Rather, she focuses on her experience of recognition by others: when the community saw her as valuable, her mother learned to see her as valuable, too.

However, having experienced rejection previously, many participants continued to fear rejection again. One young mother, for example, wrote in a monthly report:

I now have big respect in my family. My parents see me now as a change[d] person. My fear is whether my mother and my father will [always] see me as a useful person.

This continued sense of vulnerability may play a role in the extent to which young mothers choose to go through local, traditional or legal structures when they experience rights violations.

\section{Exercising rights claims}

The next several quotes and examples illustrate how and when participants were able to claim their entitlements to rights. All of these incidents happened at least several months into the PAR and, we argue, would not have occurred had the young mothers not already felt empowered with respect to self, other girl mothers, community, and family. The young mother quoted below describes how prior to the PAR, she would not have availed herself of the structures to protect her within the community. With her new self-respect and her shifted role within the community, however, she feels able to use these structures.

Before the PAR came, I was not considered worthy in the community. If there was fighting and I was walking nearby, someone would automatically blame me even if I was not at fault. Now if the community sees me in conflict or if something is stolen, they do not blame me. They see me taking care of myself and they see my business is going well and so when I complain of something, they listen to me and believe my side of the story.

Another young woman described: 
My boyfriend beat me when I wouldn't loan him money. But we went to the chief. Before he wouldn't support me and now he wants my money. We decided to separate. He took one of our children and I kept the other one. I am not happy that we're separated, but I was not going to give him my money and I was not going to tolerate him beating me. Before I wouldn't have gone to the chief because I didn't have confidence because I was provoking people in the community. But now I know my rights, I stand like a woman so I can go to the chief.

Both of these women report that they would not have previously had their perspectives believed by the community or the chief, or even availed themselves of these resources for judgment and arbitration. However, now that they believed themselves worthy of respect and experienced respect from the community, they were able to protect themselves from continued violations in the form of theft and domestic violence. Although the same structures for addressing conflict in the marketplace or in the home were in place prior to the PAR, the young women were effectively excluded from using these structures because of their marginalized status. Feeling entitled to respect, dignity, and rights, and believing that others validate their entitlement, allowed them to engage with the structures that protect the fulfillment of these rights.

Another young woman shared this story three years into the PAR. We use this example to illustrate how significant barriers to women's full enjoyment of their rights still remain:

My husband sometimes beats me. But I have nowhere to take him. It is difficult to take him to the police, as he will drive me away. Where will I take my children? I have to be patient. While this young woman did not choose to leave her husband or to seek support from the chief, she does write that 'sometimes when I have problems at home and attend meetings, my problems will go away'. Another young mother from her group said, 'you bring your enemy to the police' not your husband. The young mothers in this group offer advice and counsel to one another, which they each claim is important for their wellbeing. However, they choose not to use the legal structures that might protect them from violence, as they fear the social and economic consequences of using these structures. In another field 
site, for example, the group of girl mothers reported that they were concerned that if they reported a problem to the police, others would say they were 'being rude' or 'you're doing what you brought back from the bush'.

The young mothers in the PAR have shown a marked preference for using local authority structures like village level elected officials or traditional chiefs over legal structures like the police. This is likely because the young mothers have developed trusting relationships with many of the local authorities through the course of the PAR. The police, however, remain more distant, and often the young mothers have had previous negative experiences with the police. One young woman, for example, said that she would not trust the police since she had previously been raped and reported it to the police who 'did not handle the matter in a satisfactory manner'.

Local authorities have been called upon to address cases ranging from abandonment to assault to theft. In most instances, the chief or leader tries to work out a settlement between the parties, often a fine or punishment that is significantly less than what might be required by law. These local settlements happen quickly and the young mothers' trust that the settlements will preserve their respect within their community. In contrast, legal action may take several months or years to come to a resolution, can be expensive to pursue, and resentment may build in the community because of the perceived disruption. In one site, for example, a young mother was brutally beaten by her boyfriend in public because she was seen talking with another man. The girls as a group decided to speak with the chief, who called a meeting with all of the participants, the boyfriend, and his family. At the meeting, the boyfriend apologized and pledged never to beat her again. When the agency focal person for the PAR in the site asked the girls why they had not told him about the incident, as he was staying nearby, the girls replied that they knew he would want to report the case to the police and they preferred to have it handled by the chief. In this case, the participants felt empowered to take action in response to the violence, but did not want to involve the legal structures. Though it could be argued that a mere apology constitutes impunity for this act of violence, the girls themselves were satisfied by the resolution achieved. 
One instance where legal authorities have been invoked is when the daughter of a young mother in the PAR was raped. In this case, the mother called several other young mothers in the PAR and together they reported the instance to the police. The agency supporting the participants contacted an organization providing legal aid to help the young mother and her daughter, and the case has been referred to the high court.

\section{Resistance to empowerment and rights claims}

Although the experience of participants in the PAR has been largely positive, there have been several instances where girls' increased sense of empowerment has met against resistance. There have been a number of examples like the one cited previously, where boyfriends or husbands demanded money from the young mothers now that they had some income of their own. In several instances the women were beaten. Some resolved the conflict like the woman above, who sought guidance from the chief, while others asked their fellow girl mothers to visit and help them settle with their husbands. Some left their husbands or boyfriends, while others chose to remain with them.

In other instances, entire communities put up resistance to the young mothers' new sense of power. In one community, for example, several women in the project expressed their desire to become active in government after learning of a new law that encouraged the political participation of women during a training conducted by the agency. According to the agency focal person at the meeting, 'Some stakeholders were not pleased with the kind of knowledge revealed to the women in particular'. These stakeholders encouraged the women and their children 'not to focus on their rights only, but [also] their responsibilities'. In this instance, it appeared that those who currently held power saw the use of a rightsbased approach through teaching about a law that allowed for full participation as disruptive. This disruption may be particularly problematic when the target population is a group that has previously been disempowered but is gaining a sense of self worth and dignity. In this case, the girl mothers' desire to become involved in politics may have threatened the position of power held by others in the community, particularly those labeled as 'stakeholders'. While they may have supported the PAR in general, when the 
girl mothers expressed a desire to claim their right to participate in politics, these stakeholders were not wholeheartedly supportive, perhaps suspecting that the participation of the young mothers could disrupt their own position within the community. In this instance, knowledge of human rights entitlements, through education about a law that codified women's right to participate in politics, was seen as potentially dangerous.

\section{Conclusion}

While human rights based approaches and empowerment approaches may have similar goals - enabling people to have dignity and lead full lives in their communities where their rights are respected - these approaches take very different paths. RBAs can be top-down, starting with legal reforms and then promoting education about rights. Empowerment approaches, in contrast, are by nature bottom-up, allowing context-specific solutions to emerge that promote dignity and the fulfillment of rights. While for some, knowledge of rights alone may be empowering, for the participants in the PAR, education about rights alone is insufficient. Empowerment has been a necessary starting point for this population to experience improvements in their ability to lead dignified lives and have their rights respected.

The participants in the PAR have repeatedly had their rights violated. Over $70 \%$ were formerly associated with armed groups and had children during the conflict. The others were included in the PAR because of their extreme vulnerability; often they were victims of sexual violence and rejection by their families. When dealing with this marginalized population, we have found that empowerment is a necessary starting point. The examples above demonstrate some of the ways that participants experience empowerment through interactions and establishing relationships that foster awareness within a person that she is worthy of respect and dignity. These empowering interactions occur within groups of girl mothers, and between girl mothers and outsiders, including study organizers, agency staff, community members, and family.

This new sense of self worth has been essential for participants in the PAR to envision themselves as deserving of rights, and as entitled to protection against rights violations. Without a sense of self worth, 
they do not see themselves as entitled to rights, nor do they feel like they have access to the structures in their community that are there to protect rights. Once the young mothers in the PAR feel entitled to their rights, they then create opportunities to feel empowered through their personal and collective struggle to improve fulfillment of their rights. Although the actions that they take may not involve using legal structures, the participants in the PAR feel empowered by the resolutions that the local authorities provide or that they come up with as a collective.

Empowerment, however, has not always lead directly to the fulfillment of rights. In several examples above girls continued to suffer abuse and violence. However, they felt that their situations were better than before the PAR began and many found creative ways that collectively they could improve their experiences, even if outsiders concerned with their human rights might still see them as living in precarious situations.

Empowerment and rights-based approaches should be considered aspects of an iterative process, which can combine to produce realization of rights and more fully empowered individuals and groups. Yet, practitioners should design RBAs to meet participants where they are, recognizing their particular capacities and needs, understanding that in some instances, targeted work to facilitate empowerment will be necessary before an RBA will be able to reach its potential to improve fulfillment of rights. In our experience working with extremely vulnerable young mothers in the context of post-conflict societies that are newly adopting human rights norms, empowerment was essential before violations of human rights were even identified as a problem. In the course of this three-year study, the participants themselves identified the authority structures that they most trusted to help them have their rights fulfilled and have violations punished. Rarely were those structures the same as those recommended by the new laws. Instead, participants used chiefs, community elders, and trusted friends to help them resolve their conflicts. Even though in some cases, the chiefs are governed by local bylaws that are influenced by international human rights standards adopted by the country, the resolutions and punishments recommended by the chiefs do not match the standards contained in the laws. These resolutions, however, 
were acceptable to the participants, as they did not risk further marginalization, economic hardship, or retribution by the community.

We believe that when the target population of an intervention is a marginalized and excluded group, efforts must first be made to promote empowerment. A rights based approach focused on education about rights norms will only make sense once those in the group see themselves as worthy of dignity and respect and individuals gain a sense of agency. The group should be encouraged to use the protection resources that they are most comfortable with, even when those resources are not the accountability mechanisms specified by law. Even then, practitioners should be aware of and take precautions to minimize the possible harms that can emerge as the group is empowered and begins to claim its rights.

\section{Works Cited}

Alsop, R. 2005. Power, Rights and Poverty: Concepts and Connections. Washington, DC: World Bank Publications.

Alsop, R. and Norton, A. 2005. 'Power, Rights, and Poverty Reduction'. in R. Alsop (ed.) Power, Rights and Poverty: Concepts and Connections. Washington, DC: World Bank Publications.

Betancourt, T.S., Simmons, S., Borisova, I., Brewer, S.E., Iweala, U., and Soudière, M.D. 2008. 'High Hopes, Grim Reality: Reintegration and the Education of Former Child Soldiers in Sierra Leone’. Comp Educ Rev. 52 (4): 565-87.

Brown, D.R., Hernández, A., Saint-Jean, G., Evans, S., Tafari, I., Brewster, L.G., Celestin, M.J., GómezEstefan, C., Regalado, F., Akal, S., Nierenberg, B., Kauschinger, E.D., Schwartz, R., and Page, J.B.. 2008. 'A Participatory Action Research Pilot Study of Urban Health Disparities Using Rapid Assessment Response and Evaluation’. Am J Public Health (98) 28 - 38.

Burman, M. and McKay, S. 2007. 'Marginalization of Girl Mothers During Reintegration from Armed Groups in Sierra Leone’. Int Nurs Rev 54 (4): 316 - 23.

Bystydzienski, J. 1992. Women Transforming Politics: Worldwide Strategies for Empowerment. Bloomington: Indiana University Press.

CARE International UK. 2005. 'Principles into Practice: Learning from Innovative Rights-Based Programmes'. Accessed 09/27/09

http://www.careinternational.org.uk/Principles\%20into\%20practice:\%20Learning\%20from\%20innovativ e\%20rights-based\%20programmes+6216.twl

Chambers, R. 1994. 'The Origins and Practice of Participatory Rural Appraisal'. World Development 22 (7): 953-69. 
Coulter, C. 2006. Being a Bush Wife: Women's Lives Through War and Peace in Northern Sierra Leone. Uppsala: Uppsala University.

Denov, M. 2007. 'Girl Soldiers and Human Rights: Lessons from Angola, Mozambique, Sierra Leone and Northern Uganda’. International Journal of Human Rights 12 (5): 813 - 36.

Foucault, M. 1980. Power/Knowledge : Selected Interviews and Other Writings, 1972-1977. C. Gordon (ed.) New York: Pantheon Books.

Freire, P. 1970. Pedagogy of the Oppressed. New York: Continuum.

Green, E. and Wessells, M. 1997. 'Mid Term Evaluation Report’. Angola: Christian Childrens Fund.

Hutchings, C. 2005. 'Rights-Based Approaches to Development’. Oxford: Oxfam.

Kabeer, N. 1994. Reversed Realities: Gender Hierarchies in Development Thought. London: Verso.

Luttrell, C. and Quiroz, S., with Scrutton, C. and Bird, K. 2007. 'Understanding and Operationalising Empowerment'. Swiss Agency for Development and Cooperation.

Mazurana, D.E., McKay, S., Carlson, K.C., and Kasper, J.C. 2002. 'Girls in Fighting Forces and Groups: Their Recruitment, Participation, Demobilization, and Reintegration’. Peace \& Conflict: Journal of Peace Psychology 8 (2): 97-123.

McKay, S., Burman, M., Gonsalves, M., and Worthen, M. 2004. 'Known But Invisible: Girl Mothers Returning from Fighting Forces’. Child Soldiers Newsletter (6): 10 - 1.

McKay, S. and Mazurana, D. 2004. Where are the Girls? Girls in Fighting Forces in Northern Uganda, Sierra Leone, and Mozambique: Their Lives During and After War. Montreal: Rights and Democracy.

McKay, S., Robinson, M., Gonsalves, M., and Worthen, M. 2006. 'Girls Formerly Associated with Fighting Forces and their Children: Returned and Neglected'. London: Coalition to Stop the Use of Child Soldiers. January.

Nyamu-Musembi, C. and Cornwall, A. 2004. 'What is the 'Rights-Based Approach' All About? Perspectives from International Development Agencies'. Institute for Development Studies Working Paper 234.

Office of the United Nations High Commissioner for Human Rights. 2006. 'Frequently Asked Questions on a Human Rights Based Approach to Development Cooperation’. New York: HR/PUB/06/8.

Parpart, J.L., Rai, S.M., and Staudt, K. 2002. Rethinking Empowerment: Gender and Development in a Global/Local World. London: Routledge/Warwick Studies in Globalisation.

Robinson, M. 2005. 'What Rights Can Add to Good Development Practice'. in Alston, P. and Robinson, M. (ed) Human Rights and Development: Towards Mutual Reinforcement. Oxford: Oxford University Press. 
Robinson, M. and McKay, S. 2005. 'A Conference on Girl Mothers in Fighting Forces and Their PostWar Reintegration in Southern and Western Africa', at The Rockefeller Foundation Bellagio Center, Bellagio, Italy.

Rowlands, J. 1997. Questioning Empowerment: Working with Women in Honduras. Oxford: Oxfam.

Smyth, I. 2007. 'Talking of Gender: Words and Meanings in Development Organisations'. Development in Practice (17): 4-5.

Uvin, P. 2002. 'On High Moral Ground'. PRAXIS The Fletcher Journal of Development Studies XVII.

—. 2004. Human Rights and Development. Bloomfield, CT: Kumarian Press.

Weingarten, K. and Cobb, S. 1995. 'Timing Disclosure Sessions: Adding a Narrative Perspective to Clinical Work with Adult Survivors of Childhood Sexual Abuse’. Family Process (34): 257-269.

Wessells, M. 2006. Child Soldiers: from Violence to Protection. Cambridge: Harvard University Press.

Worthen, M. 1994. 'What Beijing Means to Me'. Advance: UNICEF newsletter. October.

Yuval-Davis, N. 1994. 'Women, Ethnicity, and Empowerment’. Feminism and Psychology 9 (3):179 - 97. 